https://doi.org/10.25312/2391-5137.14/2020_14bnl

Beata Nawrot-Lis (iD) https://orcid.org/0000-0001-6473-8010 Uniwersytet Technologiczno-Humanistyczny im. Kazimierza Pułaskiego w Radomiu e-mail: b.nawrot-lis@uthrad.pl

\title{
Language in CLIL settings: research overview
}

\begin{abstract}
This article presents an overview of the literature relating to the effects of the Content and Language Integrated Learning (CLIL) approach on the process of language and content acquisition. The overview is divided into five sections and the effects of CLIL on the students' language system is described according to four language skills (reading, writing, speaking and listening, vocabulary and grammar). It is stated that while CLIL leads to a general improvement in relation to language proficiency, there are also some observations proving that certain language areas (e.g. syntax, pragmatics) are unaffected.
\end{abstract}

Keywords: CLIL, bilingual education, effects, students, language skills

\section{Preliminary notes}

Various forms of bilingualism have been present in Europe for several millennia and CLIL has become a solution for devoting more time to foreign language learning in European schools. Mehisto and Marsh (2008: 9) explain that CLIL is "a dual-focused educational approach in which an additional language is used for the learning and teaching of both content and language".

Though research on CLIL is relatively young, some studies in this field have already been conducted. These studies concern both language and content acquisition. This article is an attempt to summarise research on the implementation of CLIL with respect to language.

It should be stated that the CLIL approach is not limited to teaching vocabulary. Since being a foreign language user is a very complex issue which implies knowledge 
of single lexical items, formulaic language, grammar, cultural awareness, it is essential not to neglect these components during CLIL courses. Although, CLIL has proven to be generally successful, the literature evaluating such programmes, draws our attention also to weaknesses in the productive skills, both spoken and written and in grammatical and sociolinguistic competence (Lyster, 2007: 16; Muñoz, 2007: 19; Pérez-Vidal, 2007: 41). In one of her papers, Dalton-Puffer (2008: 8) contrasts areas of language where certain benefits are observable with areas that seem to be unaffected.

Table 1. Language competencies favourably affected or unaffected by CLIL (Dalton-Puffer, Smit, 2008: 5)

\begin{tabular}{|l|l|}
\hline \multicolumn{1}{|c|}{ Favourable affected } & \multicolumn{1}{c|}{ Unaffected or Indefinite } \\
\hline Receptive skills & Syntax \\
\hline Vocabulary & Writing \\
\hline Morphology & Informal/non-technical language \\
\hline Creativity, risk taking, fluency, quantity & Pronunciation \\
\hline Emotive/affective factors & Pragmatics \\
\hline
\end{tabular}

The table above enumerates several language elements influenced positively in CLIL settings, such as vocabulary, reading, listening, morphology or fluency. Nevertheless, a similarly broad group of language elements has been defined as unaffected or indefinite (e.g. grammar, writing, pronunciation, pragmatics). Such a juxtaposition indicates that some hypothetical language benefits of CLIL require further verification by means of empirical data.

\section{Reading}

The following discussion emphasizes some general tendencies observed within CLIL educational settings where certain aspects of language competence are developed more than others. The overview begins with the presentation of data in relation to reading achievements in CLIL.

Merisuo-Storm (2014: 72) examines the case of a study in Finland which aimed at monitoring pupils during their first two years at school. The main aim of the study was to find out if bilingual education affects the development of students' first language literacy skills negatively or if children in CLIL education achieve the same level of literacy as their peers who study exclusively in Finnish. The development of the pupils of six classes in three schools in Southern Finland was observed from the beginning of first grade to the end of sixth grade. At the beginning of the first school year there were 138 pupils in these classes, 78 of them studied in the CLIL groups and 58 in the "traditional" classes. In the CLIL classes 20-25 per cent of the teaching was carried out in English.

The pupils' level was measured at the very beginning of their first school year (6-7 years old). Aninitial test assessed their general level of school readiness, auditory and visual perception, mathematic skills and memory. The results indicated that the pupils in the 
CLIL classes had, as a group, better initial skills than the pupils in the other classes. However, the author also points out that on the one hand, there were also pupils who showed excellent performance in the initial test in the control group and on the other hand, there were pupils who had poor initial skills in the CLIL classes.

Three reading tests were used to measure the pupils' reading skills at the end of the first, the second, and the sixth school year. In first and second grade the reading tests included reading aloud and reading comprehension tasks and in sixth grade the reading test measured the pupils ability to comprehend different kinds of texts. During the last weeks of the sixth school year the pupils' reading comprehension skills were assessed with a test that consisted of three different texts. Moreover, the focus was on the pupils' ability to derive the meaning of a word from the written context and to summarise a text.

The results of the study proved that after the first and the second school year the pupils in the CLIL groups read with greater accuracy and speed than the pupils in the other classes. After two school years especially the reading comprehension skills were significantly better in the CLIL classes than in the other classes $(t=7.10, p=.000)$. The findings of the study indicated that the CLIL students developed better reading skills than those who were studying exclusively in their native language, Finnish.

We also find some data in relation to reading in CLIL in the work by Skogen (2013: 18). The author examined whether Content and Language Integrated Learning (CLIL) and English as a Foreign Language (EFL) students at the $10^{\text {th }}$ grade of lower secondary school differ with regard to reading proficiency and reading strategy use.

The research was based on a mixed methods approach using an IELTS reading test and a questionnaire, in combination with semi-structured interviews with teachers and students. Two lower secondary schools were involved in the study, with one CLIL class and one EFL class from each school.

The results from the IELTS test and questionnaire were entered into SPSS and analysed in a form of descriptive statistics, and displayed in tables. The interviews were recorded, transcribed and finally analysed using six sets of codes, of which three were related to problems occurring when reading and using reading strategies. The analysis was also an attempt to assess whether students were challenged when reading. These codes were derived from theory and research on the reading process, foreign language reading, reading strategies, second language acquisition and CLIL.

The results of the study imply that the CLIL group reached the highest average score from the test with a score of 7.5. In addition it was characterised by the lowest standard deviation, meaning that the scores in this group varied less from the mean than for the remaining groups.

It was also evident that mostly respondents from the CLIL group admitted to having used reading strategies on the test.

The results of the study indicated that the groups differed with regard to levels of reading proficiency, motivation for reading as well as reading strategy use. The findings proved that the CLIL group scored markedly higher on the IELTS test and in their use of reading strategies when answering this test. 
Research into reading and writing skills in CLIL settings may also be found in Poland. One of the studies was conducted at the Academy of Technology and Humanities in Bielsko-Biała during the 2006/2007 academic year by Loranc-Paszylk (2009: 50). The CLIL group received lectures on the History of European Integration in English for 90 minutes per week during 2 semesters. The CLIL group worked with a variety of course materials such as: academic textbooks, Internet resources, handouts prepared by the teacher. The aim of the research was to assess the students' achievement and progress in selected English language skills (reading and writing) among the students of the CLIL (experimental) group and the remaining students (control group). The researcher used the standard tests from respective sections of Cambridge ESOL exam and IELTS3, as research instruments. The testing was carried out in two sessions: at the beginning and at the end of the course. The data collected demonstrated that the CLIL group had made significant progress in the Academic Reading test (21\%) and in the Academic Writing test $(24 \%)$. The control group's results indicated minimal progress as their students' results were stunningly low (only 1\%) in the Academic Reading test and (1\%) within the Academic Writing component.

As may be deduced from the data presented by Loranc-Paszylk, there is a huge discrepancy between the results gained by the CLIL group and the control group. However, only $1 \%$ of progress in the case of the control group appears to be an amazingly low result, which evokes further questions with respect to the research conducted. How is it possible that the control group gained so drastically low scores in the final reading test? What are the possible explanations for the situation (e.g. the choice of the teacher)? Furthermore, the author of the research does not mention whether the pre-test and the post-test applied was the same test or whether they were differentiated. Also, we are not informed about the additional materials available to the control group.

The following subsection deals with the effectiveness of CLIL as far as writing skills are concerned.

\section{Writing}

To begin with, Merisuo-Storm (2014: 72) in Finland indicated that the development of the students' writing skills during their first year at school did not show any remarkable difference between those who were taught in Finnish and those who were taught in a second language. The study included 80 students who were studying in a CLIL class and the comparison group included 59 pupils who were learning exclusively in Finnish.

The students' spelling skills were measured in first, second, and sixth grade with writing from dictation tests. At the end of the first school year, there was no significant difference in pupils' spelling skills in the bilingual classes and the other classes. However, after the second study year the students in the CLIL classes made significantly less spelling errors than the students in the other classes $(t=4.83, \mathrm{p}=.000)$.

At the end of the sixth school year the students in the CLIL classes presented significantly better spelling skills than their peers in the other classes $(t=4.22, p=.000)$. 
At fourth grade, the focus of the research was on the students' creative writing. They were asked to write a story about someone's journey to a place that is very different from where he or she lived. The writers were encouraged to use rich and colourful language, and invent interesting and amusing events. The research findings indicated that the CLIL students' language was significantly more often colourful and rich than the language in the stories written in the remaining classes $(t=5.19, \mathrm{p}=0.000)$.

There were 138 stories altogether. When selecting the twenty best stories out of them, the main criteria that were used were their "individuality, eventfulness, story structure, rich and colourful language, and fluency of narration" (Merisuo-Storm, 2014: 76). Of the twenty best stories selected, seventeen came from the CLIL groups and only three from the other classes.

One may encounter similar findings in a paper by another Finnish researcher, Rahman (2001: 72), whose study looked into the spelling of compound nouns of CLIL learners at the $6^{\text {th }}$ grade level. The results of the research proved that the learners in CLIL succeeded better than their peers learning in their mother tongue when they had to write essays in which the focus was on the correct spelling of compound nouns.

Another important study is mentioned by Dalton-Puffer (2008: 7). The author enumerates two studies conducted in Germany and Spain (Llinares, Whittaker, 2012: 48) which have investigated writing skills of secondary school students through post-teaching writing tasks in social science subjects. In both cases, there have been many deficiencies found in relation to the fulfilment of the required discourse function, cohesion and coherence, grammar or appropriate style. It is vital to add that parallel results were obtained on writing tasks completed in the learners' mother tongue. What is at issue here clearly is the role of writing in content-teaching in general, irrespective of the language it is conducted in.

Roquet (2011: 114), conducted the study which was to assess effects of the CLIL approach on young EFL learners' productive and receptive skills in a school in Barcelona. For that purpose, two groups involving 100 bilingual Catalan/Spanish students aged 12 to 15 were analysed longitudinally over two academic years in two different types of exposure contexts: FI (Formal Instruction of English as a foreign language school subject, control group) and CLIL (English as medium of instruction when learning Science, experimental group). Data were elicited both for productive and comprehension skills and were statistically analysed quantitatively and also qualitatively using a posttest design at the end of each academic year. Results obtained confirm the effectiveness of the CLIL programme, however, to various degree in the case of the skills assessed. Concerning receptive skills, when contrasting the differential effects of the two programmes on the participants' linguistic progress, the CLIL group improved their reading competence significantly more than the FI group. However, such positive findings have not been observed in relation to the students' listening skills. When it comes to productive skills, the findings proved a significant improvement in the case of the CLIL group, the learners' writing, especially their accuracy and lexico-grammatical abilities progressed significantly.

Also Lasagabaster (2011: 6) reports research which measured the learners' writing skills. Two groups of students were involved in the research: the students who were enrolled in CLIL programmes and the students who followed an EFL approach and who 
only had exposure to EFL in the traditional way. In order to measure the students' writing competence, the learners were asked to write a letter to an English family with whom they were supposed to stay in the summer. They were given total freedom regarding the approach to use and could utilise the syntactic structures and vocabulary they thought best. The results of the study proved that CLIL seems to bear rich fruits in both the oral and written skills. Both groups differed with regard to levels of writing proficiency and it was CLIL students who proved to be more advanced writers.

\section{Speaking and listening}

The following part of the article will be devoted to oral competences in CLIL. Researchers exploring qualitative aspects of CLIL learner talk, agree that there is a need to look at what Gassner and Maillat label "high-organisational structures", such as turn-taking mechanisms, argument construction and repair (2006: 17). Research into teacher-learner interaction in CLIL classrooms has focused on certain key areas, notably code switching (Nikula, 2007a: 211) or the ubiquitous IRF exchange (Nikula, 2007b: 194). It is generally admitted that CLIL learners demonstrate good interactive skills (Moore, 2011: 532). The author quotes the study by Burmeister and Daniel (2002: 504) which focuses on oral competence "particularly cohesion and turn-taking" recorded amongst learners in the Kiel IM Project (experimental group) and non-IM students (control group). The project investigated the overall linguistic outcomes of late-partial immersion amongst secondary students aged 12-13 and 15-16. The research proved that in comparison to students taught in their native language, even the younger bilingual students (after seven months of the CLIL course) were less dependent on interviewer prompts and more likely to link contributions to either their own or peer input. The researchers also stated that when studying a taxonomy of turns (requests, answers, interrupts) they found that CLIL students produced more links and acknowledges but fewer answers in comparison to their non-CLIL peers. The overall result of the research implied that CLIL learners display greater initiative and more involvement and their interaction is more effective.

Hüttner and Rieder-Bünemann (2007: 22) explored the oral narrative competence of a group of 12-year-old Austrian CLIL and Mainstream (MS) students who had been participating in a CLIL course since the beginning of primary education (for seven years). The researchers were trying to evaluate the degree to which the pupils recreated the three key plot elements of the story. The main finding was that the CLIL learners were able to provide a complete onset/unfolding/resolution sequence more successfully. Both researchers suggest that CLIL students appear to verbalise their messages more easily.

A more global view of the relation between CLIL and students' speaking skills may be found in the study by Mewald (2007: 168) who concluded that CLIL learners were "able to speak fluently, with a rich lexical range and a good command of grammar" and that, in comparison with their MS counterparts, "CLIL learners were not just more accurate but also more resourceful" (2007: 168). It is worth adding that Mewald selected learners from different schools and with mixed learning backgrounds. 
In one of her papers, Moore (2011: 532) explores the emergence of collaborative interaction among early secondary learners in bilingual sections at state schools in Andalusia. The researcher was transcribing and subsequently analysing data from oral interviews conducted with randomly selected pairs of CLIL learners and mainstream (MS) students. Moore was mostly focusing on turn-taking patterns. She was trying to identify them and then examined them for patterns of functional use. The main research finding was that the CLIL learners are participating both more frequently and more effectively in collaborative turns than their MS counterparts (Moore, 2011: 545).

We also find some information about the relation between CLIL and students' speaking skills in Ruiz de Zarobe (2008: 67). The author's aim was to analyse the differences between CLIL and English-as-a-foreign language (EFL) instruction in the case of bilingual students learning English in Spain. In order to collect the data, participants were asked to complete a speech production test. The speech production task consisted of elicited narratives of the "Frog, where are you?" story by Mercer Mayer (1969). The oral narrative was elicited through a sequence of 24 pictures. For the purpose of the analysis on speech production, five categories were used: pronunciation, vocabulary, grammar, fluency, content. The results of the research indicated that "the CLIL groups significantly outperform the non-CLIL group in every single one of the scales analysed" (Ruiz de Zarobe, 2008: 67).

\section{Grammar}

Grammatical proficiency has also been explored among CLIL and immersion students. There has been a number of studies in Finland and other countries that have compared mainstream and CLIL education. The results have proved that instructed L2 learners produce more accurate target language than CLIL learners (e.g. Genesee, 1987: 31; Nikula, Marsh, 1999a: 90; Swain, 1996: 109). Cummins and Swain (1986: 112) state that, in comparison to native speakers of the target language, CLIL and immersion students operate with simpler verb structures. Some researchers have assumed that the explanation for these findings may lie in the meaning-focused nature of CLIL that emphasizes the implicit, natural acquisition of the L2. It happens very often that there is little or no formal, explicit L2 instruction in CLIL settings. There is a tendency for a CLIL teacher to ignore grammatical accuracy if the students manage to get their messages across (Nikula, Marsh, 1999b: 80). Nowadays, however, many findings speak in favour of integrating explicit, form-focused L2 instruction to the CLIL classroom (Ellis, 2002: 224; Lyster, 2004: 411; Spada, Lightbown, 2008: 184).

Korpela (2013: 66) also compared the grammatical proficiency of an L2 between CLIL learners and mainstream students in one of the primary schools in Helsinki. Her main aim was to analyse and interpret what kind of differences are to be found in the grammatical proficiency of the two groups and what type of errors the learners produce. The results concerning the learning outcomes of CLIL were promising. The researcher claims that CLIL students outperformed the mainstream students in all areas of grammatical proficiency that this study focused on: the implicit knowledge of English measured by gram- 
maticality judgments, the structural knowledge of English measured by a cloze passage or "fill-in-the-gaps" exercise, and productive skills in English measured by a translation exercise and a written composition (Korpela, 2013: 66). What is more, the CLIL students' skills were more homogeneous. According to Korpela, explicit instruction combined with natural foreign language acquisition in the CLIL classroom leads to successful learning outcomes and improves grammatical accuracy.

Furthermore, the research by Zydatiß (2006: 21) proved that the third person -s, irregular past tenses and the modals have gained a higher degree of automatization and appropriacy of use among the CLIL learners. Zydatiß tested learners' proficiency in four areas, grammar was one of these, by using an achievement and proficiency test. His findings indicated that the CLIL students greatly outperformed the EFL learners in grammatical correctness. Using the Lambda test to present the difference of achievement by percentages, CLIL learners scored $51 \%$ better in their use of grammatical structures. Overall, the test scores suggested that the CLIL learners were $60 \%$ better in their linguistic and communicative competence than their EFL peers were.

\section{Vocabulary}

CLIL approaches are considered especially beneficial in lexical development. Dalton Puffer claims that "CLIL learners possess larger vocabularies of technical and semi-technical terms and possibly also of general academic language which gives them a clear advantage over their EFL-peers" (Dalton-Puffer, 2008: 5).

Agustín-Llach and Canga (2014: 216) conducted research to compare the receptive vocabulary size and lexical growth of a group of CLIL learners and of traditional EFL learners. They studied the receptive vocabulary size of 58 learners in a CLIL programme and of 49 traditional EFL students. The $2 \mathrm{k}$ VLT was used as a tool of measurement. Results revealed that students' receptive vocabulary sizes lie within the most frequent 1,000 words, however, CLIL students reached significantly higher vocabulary scores in the last grades tested. The vocabulary size of CLIL learners was increasing with each grade, which is why the researchers believe that the CLIL approach offers a benefit for vocabulary acquisition.

We also find important data concerning the relationship between learning and developing vocabulary and learning English in CLIL classes, among Iranian EFL learners of SAMA schools. The study proved that the students of SAMA school have the ability to develop and retain vocabulary better than ordinary school students because of the Content and Language Integrated Learning (CLIL) method and textbooks which are used for science and mathematics (Neda, Hamidreza, 2014: 2008). 40 CLIL students (in SAMA schools) and 40 students of an ordinary school participated in the study. The research method was quantitative and data were gathered through a researcher-made tool. In SAMA schools mathematics and science are taught in English and the rest of school curriculum is taught in Persian.

Merikivi and Pietila (2014: 32) have conducted the study relating to vocabulary size attained in two learning environments, in regular mainstream instruction and in CLIL classes. 
The researchers compared receptive and productive vocabulary sizes of sixth-graders from both environments with the respective vocabulary sizes of corresponding ninth-graders using the Vocabulary Levels Test and the Productive Vocabulary Levels Test. The main finding was that CLIL students are characterised by a wide range of vocabulary, as CLIL offers learners more extensive and versatile exposure to the target language.

Another research on vocabulary in CLIL settings was conducted and interpreted by Xanthou (2011: 119). The researcher examined whether students involved in CLIL are able to learn content through the medium of L2 and simultaneously exhibit significant gains in L2 vocabulary knowledge. Two experiments were set up in two public primary schools. In each experiment, there were two groups of $6^{\text {th }}$ grade students involved. Each teacher had to teach the same content to two different classes. The first class was taught content through L1 whereas the second class was through L2. The two teachers strictly adhered to the same lesson plans in order to control for differences in the teaching styles between them. The first group was taught three 80-minute science lessons through the medium of L2 English, while the second group was taught the same content through the medium of L1 Greek. Pre-tests were administered one week before treatment, while post-tests were administered four days after the day of attending the last lesson in order to examine retention. The outcomes demonstrated a significant effect of CLIL on L2 vocabulary knowledge of the experimental groups, which outperformed the control groups that were not exposed to CLIL.

We may also find positive results in relation to vocabulary learning in CLIL in the work by Seregely (2008: 29), who was comparing the results of CLIL students and learners in traditional EFL classes using five vocabulary tests and questionnaires. The main finding was that the CLIL students significantly outperformed their traditional peers.

An opposing point of view may be found in Seikkula-Leino (2007: 331) who quotes the findings by a Finnish researcher (Hamalainen, 1998: 54) concerning the development of vocabulary in the students' mother tongue from the second to fifth grade. The results proved that CLIL learners, especially in upper classes, demonstrated weaker vocabulary skills in comparison to their peers in traditional Finnish classes. The research included 139 pupils in CLIL group and 170 students in Finnish language teaching and the vocabulary test was focused on nature and the environment protection.

\section{Summary}

The following subsection of the article presents an overview of literature data relating to the effects of the CLIL approach on the process of language learning between 2007 and 2014. The following table juxtaposes the research findings with reference to European countries and language skills studied. 
Table 2. The comparison of the results of CLIL and non-CLIL students

\begin{tabular}{|l|l|l|}
\hline Country & Language skill & Results of CLIL students compared to non-CLIL students \\
\hline \multirow{3}{*}{ Austria } & Speaking & Superior \\
\cline { 2 - 3 } & Vocabulary & Superior \\
\hline \multirow{5}{*}{ Germand } & Reading & Superior \\
\cline { 2 - 3 } & Writing & superior / the same \\
\cline { 2 - 3 } & Grammar & Superior \\
\cline { 2 - 3 } & Vocabulary & Superior / weaker \\
\cline { 2 - 3 } & Writing & Superior / weaker \\
\cline { 2 - 3 } & Speaking & Superior \\
\hline Greece & Vocabulary & Superior \\
\hline Norway & Reading & Superior \\
\hline Poland & Reading & Superior \\
\hline Spain & Writing & superior / weaker \\
\cline { 2 - 3 } & Speaking & Superior \\
\cline { 2 - 3 } & Vocabulary & Superior \\
\hline
\end{tabular}

Information found in the table suggest that CLIL literature points to many beneficial effects the approach has on the students' language skills. In this matter, CLIL has proven to be generally successful.

It may also be noticed that the most frequently studied language aspect was vocabulary development. The second position belongs to productive skills, both speaking and writing have been evaluated by many European researchers. In relation to receptive skills, it was reading which proved to be supported by CLIL approach. Finally, the area which appears to be the least frequently monitored in CLIL settings is grammar. The observations and results stated in the article may influence future researchers to pursue further studies in the field of CLIL with the hope that the data presented will encourage teachers to begin their own adventures with CLIL on a regular basis.

\section{References}

Agustín-Llach M., Canga A. (2014), Vocabulary growth in young CLIL and traditional EFL learners: evidence from research and implications for education, "International Journal of Applied Linguistics", no. 26, p. 211-227.

Burmeister P., Daniel A. (2002), How effective is late partial immersion? Some findings from a secondary school program in Germany, [in:] Burmeister P., Piske T., Rohde A. (ed.), An Integrated View of Language Development, Trier.

Cummins J., Swain M. (1986), Bilingualism in Education, London.

Dalton-Puffer C., Smit U. (2008), Empirical Perspectives on CLIL Classroom Discourse, Frankfurt-Wien. 
Ellis R. (2002), Does form-focused instruction affect the acquisition of implicit knowledge? A review of the research, "Studies in Second Language Acquisition", no. 24, p. 223-236.

Gassner D., Maillat D. (2006), Spoken competence in CLIL: A pragmatic take on recent Swiss data, "ViewZ - Vienna English Working Papers", no. 15, p. 15-22.

Genesee F. (1987), Learning Through Two Languages. Studies in Immersion and Bilingual Education, Cambridge.

Hamalainen M. (1998), Aidinkielen kehittyminen vieraskielisessa opetuksessa, Turku.

Hüttner J., Rieder-Bünemann A. (2007), The effect of CLIL instruction on children's narrative competence, "ViewZ - Vienna English Working Papers", no. 16, p. 20-28.

Korpela L. (2013), Learning English Grammar in Content and Language Integrated Learning: Comparing the Grammatical Proficiency of CLIL Students and Students Receiving Mainstream EFL Instruction, https://helda.helsinki.fi/handle/10138/42771 [access: 16.01.2020].

Lasagabaster D. (2011), English achievement and student motivation in CLIL and EFL settings, "Innovation in Language Learning and Teaching", no. 5, p. 3-18.

Llinares A., Whittaker R. (2012), The roles of language in CLIL, Cambridge.

Loranc-Paszylk B. (2009), Integrating Reading and Writing into the Context of CLIL Classroom: Some Practical Solutions, "International CLIL Research Journal", no. 1, p. 47-53.

Lyster R. (2004), Differential effects of prompts and recasts in form-focused instruction, "Studies in Second Language Acquisition", no. 26, p. 399-432.

Lyster R. (2007), Learning and Teaching Languages Through Content. A counterbalanced approach, Philadelphia.

Mehisto P., Marsh D. (2008), Uncovering CLIL, London.

Merikivi R., Pietila P. (2014), The Impact of Free-time Reading on Foreign Language Vocabulary Development, "Journal of Language Teaching and Research", no. 5, p. 28-36.

Merisuo-Storm T., Soininen M. (2014), Students' First Language Skills After Six Years in Bilingual Education, "Mediterranean Journal of Social Science", no. 5, p. 72-81.

Mewald C. (2007), A comparison of oral foreign language performance of learners in CLIL and in mainstream classes at lower secondary level in Lower Austria, [in:] Dalton-Puffer C., Smit U. (ed.), Empirical perspectives on CLIL classroom discourse, Frankfurt am Main.

Moore P. (2011), Collaborative interaction in turn-taking: a comparative study of European bilingual (CLIL) and mainstream (MS) foreign language learners in early secondary education, "International Journal of Bilingual Education and Bilingualism", no. 14, p. 531-549.

Muñoz C. (2007), CLIL: Some thoughts on its psycholinguistic principles, "Revista española de lingüística aplicada", no. 1, p. 17-26.

Neda Z., Hamidreza F. (2014), The Effect of CLIL on Vocabulary Development by Iranian Secondary School EFL Learners, "Procedia - Social and Behavioral Sciences", no. 98, p. 2004-2009.

Nikula T. (2007a), Speaking English in Finnish content-based classrooms, "World Englishes", no. 26 , p. 206-223. 
Nikula T. (2007b), The IRF pattern and space for interaction: Comparing CLIL and EFL classrooms, [in:] Dalton-Puffer C., Smit U. (red.), Empirical perspectives on CLIL classroom discourse, Frankfurt.

Nikula T., Marsh D. (1999a), Focus on the classroom, [in:] Marsh D., Langé G. (ed.), Implementing Content and Language Integrated Learning. A Research-driven TIE-CLIL Foundation Course Reader, Jyväskylä.

Nikula T., Marsh D. (1999b), Language learning in CLIL, [w:] Marsh D., Marshland B. (red.), Learning with Languages. Professional Development Programme for Introducing Content and Language Integrated Learning, Jyväskylä.

Pérez-Vidal C. (2007), The need for focus on form (FoF) in Content and Language Integrated approaches: An exploratory study, "Revista española de lingüística aplicada", no. 1, p. 39-54.

Rahman H. (2001), Kaksikielisen (suomi-englanti) ja suomenkielisen kuudennen luokan aidinkielen kirjoitelmien vertailua yhdyssanojen oikeinkirjoituksen osalta, Helsinki.

Roquet H. (2011), A study of the acquisition of English as a foreign language: Integrating content and language in mainstream education in Barcelona, Barcelona.

Ruiz de Zarobe Y. (2008), CLIL and Foreign Language Learning: A Longitudinal Study in the Basque Country, "International CLIL Research Journal”, no. 1, p. 60-73.

Seikkula-Leino J. (2007), CLIL Learning: Achievement Levels and Affective Factors, "Language and Education", no. 21, p. 328-341.

Seregely E. (2008), A comparison of lexical learning in CLIL and traditional EFL classrooms, Vienna.

Skogen M. (2013), Reading in CLIL and in regular EFL classes: to what extent do they differ in reading and strategy use? Oslo.

Spada N., Lightbown P. (2008), Form-Focused Instruction: Isolated or Integrated? "TESOL Quarterly", no. 42, p. 181-207.

Swain M. (1996), Discovering Successful Second Language Teaching Strategies and Practices: From Programme Evaluation to Classroom Experimentation, "Journal of Multilingual and Multicultural Development", no. 17, p. 105-113.

Xanthou M. (2011), The impact of CLIL on L2 vocabulary development and content knowledge, "English Teaching: Practice and Critique", no. 10, p. 116-126.

Zydatiß W. (2006), Bilingualer Fachunterricht in Deutschland: eine Bilanz, "Fremdsprachen Lehren und Lernen", no. 36, p. 8-25. 


\section{Streszczenie \\ Wpływ zintegrowanego kształcenia przedmiotowo-językowego na sprawności językowe uczniów - przegląd literatury}

Niniejszy artykuł zgłębia potencjał nauczania metodą CLIL i analizuje możliwe korzyści oferowane przez edukację dwujęzyczną. Prezentuje on przegląd literatury oraz gruntowną analizę badań w zakresie zastosowania metody CLIL w nauczaniu języków obcych. Literatura oceniająca programy CLIL, mimo ich ogólnego sukcesu, zwraca również uwagę na słabości uczniów w odniesieniu do sprawności produktywnych, zarówno mówienia jak i pisania oraz do kompetencji gramatycznych i socjolingwistycznych. Intencją autorki artykułu było przedstawienie dowodów dowodzących skuteczności nauczania metodą CLIL oraz zachęcenie przyszłych badaczy do dalszego zgłębiania tej tematyki.

Słowa kluczowe: Zintegrowane kształcenie przedmiotowo-językowe, nauczanie dwujęzyczne, efekty, uczniowie, sprawności językowe 